\title{
The applications of timed artificial insemination and timed embryo transfer in reproductive management of dairy cattle
}

\author{
Divakar Justus Ambrose ${ }^{1,2}$, Marcos Germán Colazo ${ }^{1}$, John Patrick Kastelic $^{3}$
}

\author{
${ }^{1}$ Agriculture Research Division, Alberta Agriculture and Rural Development, Edmonton, Canada. \\ ${ }^{2}$ Agricultural Food and Nutritional Science, University of Alberta, Edmonton, Canada. \\ ${ }^{3}$ Agriculture and Agri-Food Canada, Lethbridge, Alberta, Canada.
}

ABSTRACT - Fertility of dairy cattle is generally decreasing. Overall estrus detection efficiency in lactating dairy cattle is low, as expression of estrus is often compromised. Consequently, undetected estrus, low AI-submission rates, and long interbreeding intervals are the main contributors to poor reproductive efficiency. Although failure to become pregnant is the most common reason for culling dairy cattle, pregnancy rates could be improved by increasing the AI-submission rate through increased estrus detection efficiency, timed insemination (Timed-AI), or timed embryo transfer (Timed-ET). In these protocols, ovarian follicular development and luteolysis are controlled, culminating in synchronous ovulation in most cows. There are several modifications to improve pregnancy rates in Timed-AI protocols, e.g. presynchronization with 2 doses of $\mathrm{PGF}_{2 \mathrm{a}} 14 \mathrm{~d}$ apart, and starting the Ovsynch protocol $12 \mathrm{~d}$ after the $2^{\text {nd }} \mathrm{PGF}_{2 \mathrm{a}}$. Timed-AI programs ensure a timely first breeding; this should be followed with early pregnancy diagnosis to identify nonpregnant cows, and prompt re-insemination. However, in a recent field study involving 23 dairy herds, the mean interval between 1 st and 2 nd breeding was $42 \mathrm{~d}$; only $28 \%$ of the cows were rebred within $24 \mathrm{~d}$ after 1 st breeding. Fortunately, there are several resynchronization protocols to reduce interbreeding intervals. Anestrus cows, or those with cystic ovarian follicles, have a good chance of conceiving when subjected to synchronization of ovulation and Timed-AI. Furthermore, Timed-ET is a practical and viable option for synchronizing and selecting recipient cattle for embryo transfers. In summary, systematic and judicious use of Timed-AI and Timed-ET protocols can greatly enhance reproductive performance, and improve herd productivity.

Key Words: cystic ovaries, gonadotropin releasing hormone, porcine luteinizing hormone, progesterone, synchronization of ovulation, ultrasonography

\section{Aplicação da inseminação artificial e transferência de embrião em tempo fixo no manejo reprodutivo de vacas leiteiras}

RESUMO - A fertilidade em vacas de leite está em decréscimo e, de modo geral, a detecção eficiente do estro em vacas lactantes é baixa, já que a expressão do estro é frequentemente comprometida. Em conseqüência desse fato, estro não detectado, baixas taxas de eficiência de IA e longos intervalos de partos são as principais causas da baixa eficiência reprodutiva. Embora a falta de capacidade para emprenhar e manter-se prenhe seja a principal razão para o descarte em rebanhos leiteiros, a taxa de prenhez pode ser melhorada pelo aumento da eficiência da IA através do aumento da eficiência de detecção de cio, inseminação artificial em tempo fixo, ou ainda transferência de embriões em tempo fixo. Nesses protocolos, o desenvolvimento folicular ovariano e a luteólise são controlados, culminando na sincronização da ovulação na maioria dos animais. Existem inúmeras modificações para aumentar as taxas de prenhez em protocolos de IA em tempo fixo, como, por exemplo, a pré-sincronização com 2 doses de PGF2a com 14 dias de intervalo, e iniciando o protocol Ovsynch 12 dias após a segunda aplicação de PGF2a. Programas de IA em tempo fixo garantem melhor controle da idade ao primeiro serviço; o qual deve ser acompanhado de um diagnóstico de prenhez precoce para identificar vacas vazias e uma rápida reinseminação. Contudo, em um recente estudo de campo com 23 rebanhos de vacas leiteiras, o tempo médio entre o primeiro e segundo serviço foi de 42 dias, sendo que apenas $28 \%$ das vacas estavam reinseminadas aos 24 dias após o primeiro serviço. Felizmente, existem vários protocolos de resincronização para reduzir o intervalo de serviços. Vacas em anestro ou com cistos ovarianos foliculares têm boa chance de emprenhar quando submetidas a protocolos de sincronização da ovulação e IA em tempo fixo. A transferência de embrião em tempo fixo é uma alternativa prática e viável para a sincronização e seleção de receptoras bovinas para transferência de embriões. Em síntese, o uso sistemático e sensato de IA e a transferência de embrião em tempo fixo podem aumentar o desempenho reprodutivo e melhorar a produtividade do rebanho.

Palavras-chave: cisto ovariano, hormônio liberador de gonadotrofina, hormônio luteinizante porcino, progesterona, sincronização da ovulação, ultrasonografia 


\section{Introduction}

The declining trend in fertility of dairy cattle is a world-wide phenomenon of great concern (Lucy, 2001; Royal et al., 2000). Although it is widely believed that there is an inverse relationship between milk production and fertility, there is no evidence for a cause-and-effect relationship. In contrast, in a recent Canadian study (based on a large dataset), each $1000 \mathrm{~kg}$ increase in mean milk production was associated with a 0.7 point increase in pregnancy rate (LeBlanc, 2010). Nevertheless, highproducing dairy cows of the 21 st century are believed to have important metabolic and physiologic challenges that contribute to poor estrous behavior, reduced blood concentrations of reproductive hormones, high embryonic mortality, and increased reproductive and metabolic disorders (Lucy, 2001). Furthermore, intensive housing systems, artificial flooring, increased herd sizes, reduced labour, and environmental factors (e.g. heat stress) impair estrus detection and reduce submission rates for artificial insemination (AI-submission rate). Although conception rates in dairy cows have declined over the years, herd pregnancy rates could be improved by increasing the AIsubmission rate through increased estrus detection efficiency, or use of timed insemination (Timed-AI) protocols which synchronize follicular growth, regression of the corpus luteum (CL), and ovulation. Similarly, timed embryo transfer (Timed-ET) could also be conveniently adopted for management of reproduction in dairy cattle.

Early work on regulation of estrous cycles in cattle began approximately 60 years ago. In those studies, longterm treatment with progesterone yielded excellent estrus synchronization, but very low conception rates. The use of estrogens to induce luteolysis enabled shorter-term progestagen treatments (primarily used in beef cattle), with better conception rates. In the early 1970's, the luteolytic properties of prostaglandin $\mathrm{F}_{2 \alpha}\left(\mathrm{PGF}_{2 \alpha}\right)$ were discovered, and this compound (and its analogs) were soon adopted for estrus synchronization of both beef and dairy cattle. In 1976, an intravaginal progesterone device was developed and protocols using a combination of progesterone and $\mathrm{PGF}_{2 \alpha}$ became available for more precise synchronization of estrus with very acceptable conception rates. The use of estradiol and gonadotropin-releasing hormone $(\mathrm{GnRH})$ in synchronization of follicle growth in cattle was reported in the early 1990's, which soon led to the development of current protocols used to synchronize ovulation. The development of various products and protocols for synchronization of estrus and ovulation in cattle have been recently reviewed (Mapletoft et al., 2005; Lauderdale, 2009).

This paper will provide a brief overview of reproductive status in modern dairy cows, mainly from a Canadian perspective, and discuss the applications of Timed-AI and Timed-ET primarily for reproductive management of dairy cattle. Due to space limitations, the bibliography is not exhaustive, but includes key references, with an emphasis on published (and unpublished) findings from the authors' research. Reproductive status of dairy herds

Reproductive failure is the Number 1 reason for culling dairy cattle, at least in North America. In a recent comprehensive study in of 23 dairy herds in Alberta, we concluded that undetected estrus, low AI-submission rates, and long inter-breeding intervals are the main contributors to poor reproductive efficiency (Ambrose $\&$ Colazo, 2007). In any 21-d interval, the proportions of eligible cows submitted for AI and becoming pregnant, were only 37 and $13 \%$, respectively, similar to the Canadian average (LeBlanc, 2005) and that of other regions of North America. In our study, the overall interval from calving to $1 \mathrm{st}$ rise in progesterone (indicative of ovulation and onset of cyclicity) was $32.0 \pm 0.7 \mathrm{~d}$. The cumulative percentages of cows initiating cyclicity by $3,6,9$, and $>9$ wk after calving were $27,75,90$, and $96 \%$, respectively; only $10 \%$ of the cows had not resumed cyclicity by 9 wk postpartum. In addition, high embryonic mortality (Bilodeau-Goeseels \& Kastelic, 2003; Inskeep \& Dailey, 2010) and cystic ovarian disease (Brito \& Palmer, 2004) also contribute to reproductive failure in dairy cattle.

\section{The concept of Timed-AI and Timed-ET}

Accurate estrus detection and timely insemination are absolutely essential for the success of AI programs. Since the introduction of $\mathrm{PGF}_{2 \alpha}$ for causing luteolysis and inducing estrus in cattle, numerous protocols have been developed (Lauderdale, 2009). It is noteworthy that none of the early protocols using $\mathrm{PGF}_{2 \alpha}$ by itself, or in combination with progesterone, was designed to synchronize ovulation. Soon after recognition of GnRH as a tool to regulate follicular growth and ovulation, protocols incorporating $\mathrm{GnRH}$ and $\mathrm{PGF}_{2 \alpha}$ were developed for synchronization of estrus (Thatcher et al., 1989; Twagiramungu et al., 1992) and ovulation (Pursley et al., 1995; Twagiramungu et al., 1995; Schmitt et al., 1996). The Timed-AI protocol commonly referred to as "Ovsynch" (Pursley et al., 1995) consists of three treatments: two injections of GnRH given $9 \mathrm{~d}$ apart, with an intervening injection of $\mathrm{PGF}_{2 \alpha}$ given $7 \mathrm{~d}$ after the $1 \mathrm{st}$ GnRH treatment, followed by AI, 16-20 h later (Figure 1, without progesterone device). 
There are several variations of the Ovsynch protocol; a common modification involves increasing the interval from $\mathrm{PGF}_{2 \alpha}$ to 2 nd $\mathrm{GnRH}$ to $56 \mathrm{~h}$, or combining the $2^{\text {nd }} \mathrm{GnRH}$ with AI, usually 56 to $66 \mathrm{~h}$ after $\mathrm{PGF}_{2 \alpha}$ (Cosynch protocol). Another variation includes the insertion of a progesteronereleasing intravaginal device at 1 st $\mathrm{GnRH}$ injection and its removal concurrent with the $\mathrm{PGF}_{2 \alpha}$ injection ( $7 \mathrm{~d}$ after $1 \mathrm{st}$ GnRH treatment; Figure 1) or $24 \mathrm{~h}$ later (Figure 2). These approaches prevent premature estrus and ovulation, further improving the synchrony of ovulation. The latter protocol has been used in dairy heifers achieving conception rates higher than with a standard Ovsynch/ Timed-AI protocol (Ambrose et al., 2005; Ambrose et al., 2008). The basic protocol for Timed-ET is identical to that of Timed-AI, with GnRH (d 0), $\mathrm{PGF}_{2 \alpha}(\mathrm{d} 7)$ and GnRH (d 9). However, instead of Timed-AI 16-20 $\mathrm{h}$ after the $2 \mathrm{nd} \mathrm{GnRH} \mathrm{(d} \mathrm{10),} \mathrm{embryo}$ transfer is performed $8 \mathrm{~d}$ after the $2 \mathrm{nd} \mathrm{GnRH}$ (d 17), with the embryo placed in the uterine horn ipsilateral to the CL.

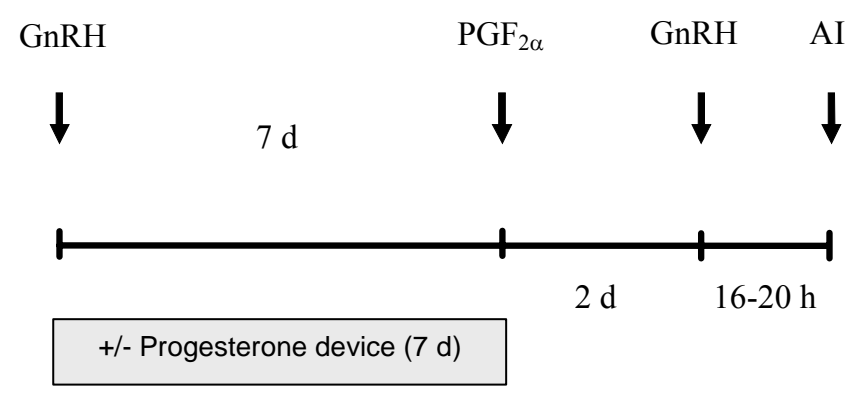

Figure 1 - Standard Ovsynch (no progesterone device inserted) or modified Ovsynch protocol (progesterone device inserted for $7 \mathrm{~d}$ ) for Timed-AI in cattle.

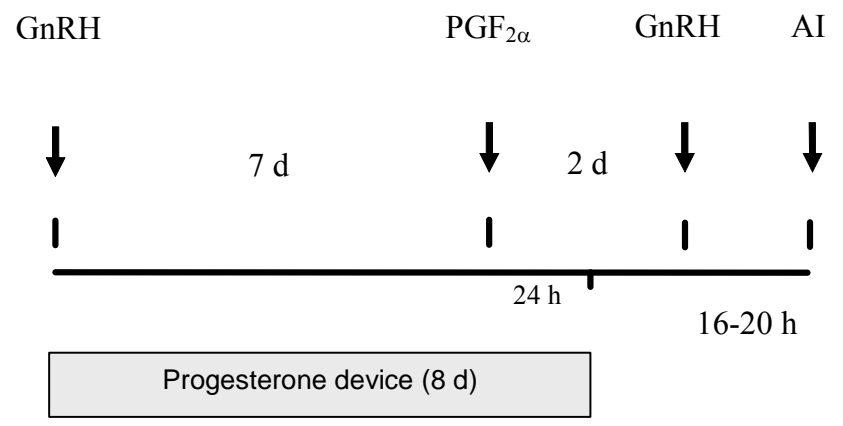

Figure 2 - Modified Ovsynch protocol for Timed-AI in cattle, including a progesterone device inserted for $8 \mathrm{~d}$ (and removed $24 \mathrm{~h}$ after $\mathrm{PGF}_{2 \alpha}$ treatment).

\section{Timed-AI to improve herd pregnancy rate}

In herds using AI, accurate and efficient detection of estrus is very important for reproductive success. Based on research conducted in the early 1990's in Ontario, Canada, Kinsel \& Etherington (1998) reported an estrus detection rate of $48 \%$. However, more recent Canadian studies have reported estrus detection rates of only 33 to $36 \%$ and conception rates of approximately 38\% (Leblanc, 2005; Ambrose \& Colazo, 2007), consistent with reports from the USA. Although calving interval and average days open are commonly used to assess herd reproductive performance, neither is highly reliable (Leblanc, 2005). Conversely, pregnancy rate is a more reliable reproductive index on a whole-herd basis. Although conception rate and pregnancy rate are often used interchangeably, they have distinctly different meanings. Whereas conception rate relates to pregnancies per AI expressed in percentage (i.e., number of cows pregnant/number of cows inseminated x 100), pregnancy rate relates to the total pregnancies among all eligible cows, regardless of whether they were inseminated (i.e., number of cows pregnant / number of cows eligible for insemination $\mathrm{x} 100$ ). Thus, pregnancy rate is a product of estrus detection rate and conception rate. Assuming that conception rates within a herd remain relatively constant over time, any improvement in estrus detection efficiency will result in higher pregnancy rates. For example, with a conception rate of $40 \%$ and estrus detection rate of $30 \%$, the pregnancy rate is $12 \%$, which is only marginally lower than the average pregnancy rate of $\sim 13 \%$ in Canadian dairy herds in recent years (Leblanc, 2005; Ambrose \& Colazo, 2007). However, improving the estrus detection rate to $50 \%$, would result in a herd pregnancy rate of $20 \%$.

Timed-AI circumvents estrus detection and improves pregnancy rates

Considering that the expression of estrus is very poor in lactating dairy cows, and overall estrus detection efficiency is far from acceptable, Timed-AI programs can overcome deficiencies in estrus detection. Although acceptable conception rates are a prerequisite for the success of Timed-AI programs, only herds with poor estrus detection efficiency will substantially benefit from regular implementation of Timed-AI.

In a preliminary study comparing Timed-AI to AI at detected estrus in dairy heifers we (Ambrose \& Kastelic, unpublished) assigned 41 heifers to an electronic mount detection system (Heatwatch ${ }^{\mathrm{TM}}$ ) and 47 heifers to a TimedAI program that included an intravaginal progesterone device (CIDR, Pfizer Canada) for $8 \mathrm{~d}$. Heifers in the TimedAI group received GnRH (Fertiline, Vetoquinol Canada) on 
Day 0, $\mathrm{PGF}_{2 \alpha}$ (Lutalyse, Pfizer Canada) on Day 7, and a 2nd GnRH on Day 9, with the CIDR device removed on Day 8 (Figure 2), and heifers Timed-AI 16-20 h after 2nd GnRH. Heifers assigned to Heatwatch were inseminated at detected estrus. Fewer heifers on the Heatwatch were submitted for AI relative to those assigned to Timed-AI. Conception rates were comparable, but pregnancy rate was significantly greater in the Timed-AI group (Table 1).

Timed-AI reduces the interval from calving to first service

An inter-calving interval of 12 to $13 \mathrm{mo}$ is often recommended for maximum profitability in dairy herds. To achieve this target, cows must conceive between 85 and 115 $\mathrm{d}$ postpartum. In the Canadian reproductive benchmarking study involving 23 herds (Ambrose \& Colazo, 2007), the mean interval from calving to 1 st service was $88.5 \pm 1.4 \mathrm{~d}$ (range, 32 to $267 \mathrm{~d}$ ). However, only 42, 62, and 77\% of the cows had been submitted for AI by 80, 100, and $125 \mathrm{~d}$, respectively. Clearly, almost $25 \%$ of cows had not been submitted for AI even once during the entire $125 \mathrm{~d}$ study period, although $76 \%$ of this population was eligible for breeding.

The single biggest advantage of Timed-AI programs is that cows can get inseminated for the 1 st time at a target date (e.g. $70 \mathrm{~d}$ ) after calving. It is well established that 1 st service pregnancy rates increase with postpartum interval. Therefore, implementation of a Timed-AI program enables the producer to withhold insemination of cows detected in estrus prior to the minimum desired postpartum interval, without concern of a prolonged interval from calving to $1 \mathrm{st}$ insemination.

Timed-AI and resynchronization programs can reduce inter-breeding intervals

At prevailing conception rates $(<40 \%)$, there is a $60 \%$ chance that the cow is not pregnant to an AI event. Therefore, early pregnancy diagnosis to identify nonpregnant cows and re-inseminate them as soon as possible is critical to achieve good reproductive performance. However, in our benchmark study (Ambrose \& Colazo, 2007), the mean interval between 1 st and 2 nd breeding was $41.6 \pm 1.7 \mathrm{~d}$ (range, 1 to $147 \mathrm{~d}$ ); only $28 \%$ of the cows were rebred within 17 to $24 \mathrm{~d}$ after 1 st breeding. The interval between the 2 nd and $3 \mathrm{rd}$ breeding was $34.2 \pm 2.9 \mathrm{~d}$ (range, 1 to $97 \mathrm{~d}$ ), and the percentage of cows rebred between 17 and $21 \mathrm{~d}$ after 2 nd breeding was the same $(28 \%)$ as that after 1 st insemination.

There are several resynchronization protocols to reduce inter-breeding intervals (Lucy, 2005). These protocols include GnRH given 20 to $31 \mathrm{~d}$ after the $1 \mathrm{st}$ Timed-AI, followed by pregnancy diagnosis $1 \mathrm{wk}$ later (27 to $38 \mathrm{~d}$ ). Cows declared nonpregnant receive $\mathrm{PGF}_{2 \alpha}$ upon pregnancy diagnosis, followed by a 2 nd GnRH injection 2 d later (Moreira et al., 2000; Galvão et al., 2007). Timed-AI may be performed either concurrent with the 2 nd GnRH injection or 16-20 h later. Another protocol is to insert a progesterone device $18 \mathrm{~d}$ after AI, remove it $7 \mathrm{~d}$ later (Day 25 post-AI) and inject GnRH at the same time. Pregnancy is determined ultrasonographically on Day 32 and nonpregnant cows are given $\mathrm{PGF}_{2 \alpha} ; 56 \mathrm{~h}$ later, the 2 nd $\mathrm{GnRH}$ is injected and cows re-inseminated $16 \mathrm{~h}$ later $(35 \mathrm{~d}$ after 1st AI) [Thatcher et al., 2008]. Using GnRH to reprogram the ovarian cycle in the 3 rd week after the previous AI is not recommended. In one study (Moreira et al., 2000), there was an apparent increase in embryonic loss between 20 and $27 \mathrm{~d}$ after Timed-AI in cows that received a GnRH injection on Day 20 post-AI. However, starting a resynchronization program by giving $\mathrm{GnRH}$ either 25 or $28 \mathrm{~d}$ after previous AI, followed by pregnancy diagnosis on Days 32 or 35 , would be an acceptable and practical alternative.

Other resynchronization protocols include the use of an intravaginal progesterone device inserted $21 \mathrm{~d}$ after $1 \mathrm{st}$ Timed-AI and removed $7 \mathrm{~d}$ later, followed by estrus detection and breeding. Alternatively, a progesterone-releasing intravaginal device may be inserted from 14 to $21 \mathrm{~d}$ after the 1 st Timed-AI, and GnRH given 3 d later ( $d 24)$, followed by pregnancy diagnosis (d 31), with nonpregnant cows receiving $\mathrm{PGF}_{2 \alpha}$ the same day, and the 2 nd GnRH given $2 \mathrm{~d}$ later (d 33). Cows may be Timed-AI at the 2nd GnRH treatment or 16-20 h later. Variations of these protocols have been reported (Galvão et al., 2007) using estradiol cypionate to synchronize ovulation, with acceptable conception rates.

Table 1 - AI-submission-, conception- and pregnancy-rates in Holstein heifers subjected to AI at detected estrus (Heatwatch), or Timed-AI

\begin{tabular}{lccc}
\hline & Timed-AI\% (No.) & AI at detected estrus\% (No.) & Probability \\
\hline AI-Submission rate & $100(47 / 47)$ & $61(25 / 41)$ & 0.01 \\
Conception rate & $72(34 / 47)$ & $46(19 / 25)$ & 0.73 \\
Pregnancy rate & $72(34 / 4)$ & $46 / 41)$ & 0.01 \\
\hline
\end{tabular}




\section{Timed-AI can benefit anestrous cows}

Although postpartum anestrus is common in dairy cows (LeBlanc, 2005; Peter et al., 2009), exogeneous GnRH can induce LH release as early as $10 \mathrm{~d}$ postpartum (Fernandes et al., 1978). GnRH-based Timed-AI protocols have been somewhat effective in initiating cyclicity (Moreira et al., 2000; Kassa et al., 2002; Stevenson et al., 2008; Colazo et al., 2009) and achieving pregnancy to Timed-AI (Table 2) in anestrous cows.

For anestrous cows to conceive, ovulation to the first GnRH treatment seems crucial.

Timed-AI for management of cystic ovarian disease

The incidence of cystic ovarian disease is up to $15 \%$ in some herds, and contributes to reproductive inefficiency (Brito \& Palmer, 2004). Exogeneous GnRH, human chorionic gonadotropin (hCG) and porcine luteinizing hormone $(\mathrm{pLH})$ are frequently used to treat ovarian cysts, but outcomes are highly variable. In the past $10 \mathrm{y}$, there are several reports regarding Timed-AI for treatment of cystic ovarian disease (Table 3).

Overall, 292 cystic cows were subjected to Timed-AI and a $28 \%$ conception rate attained, compared to a conception rate of $33 \%$ in 1295 normal cyclic cows subjected to comparable treatments. Clearly, Timed-AI is a viable approach to get cystic cows pregnant. Ambrose et al. (2004) previously monitored ovarian changes in response to the Ovsynch treatment in 18 cystic cows. Ten of the 18 cows had at least one cystic follicle $>25 \mathrm{~mm}$ in diameter (in the absence of a CL), and 8 cows had a cyst and a CL.

Table 2 - Pregnancy rates after Timed-AI in apparently anestrous dairy cows

\begin{tabular}{lcccc}
\hline Cows (n) & \multicolumn{2}{c}{ Pregnancy $(\%)$} & $P$ & Reference \\
\cline { 2 - 3 } $\begin{array}{l}\text { Anestrous/ } \\
\text { Total }\end{array}$ & Anestrous Cyclic & & \\
\hline $24 / 327$ & 18.2 & 39.0 & $<0.02$ & Moreira et al. (2000) \\
$174 / 1067$ & 24.7 & 37.8 & $<0.05$ & Stevenson et al. (2008) \\
$45 / 366$ & 24.4 & 30.8 & $>0.05$ & Colazo et al. (2009) \\
\hline
\end{tabular}

Despite the presence of a large cyst, a new follicle developed in response to the 1 st GnRH treatment in all 18 (100\%) cows. Fifteen of the 18 cows $(83 \%)$ ovulated the newly developed follicle in response to the $2^{\text {nd }} \mathrm{GnRH}$ treatment, and all developed a new CL. Seven of the 17 cows presented for pregnancy diagnosis were confirmed pregnant 32-40 d after Timed-AI. Although the cyst was present for up to $40 \mathrm{~d}$ after Timed-AI in $65 \%$ of the cows, it had no detrimental effect on pregnancy establishment.

Diagnosis of ovarian cysts in all cows assigned to the above studies was largely based on a single examination of the ovaries. However, in a Spanish study (López-Gatius \& López-Béjar, 2002), ovaries were examined by ultrasound once a week over a 21 -d period and cows were considered cystic only if a large follicle $(\geq 25 \mathrm{~mm})$ in the absence of a CL was detected at all three observations. Multiple examinations increase the probability for identifying "true" ovarian cysts; therefore, cysts diagnosed in this manner may be considered active cysts. When 64 cows diagnosed with such active ovarian cysts were subjected to Ovsynch/ Timed-AI, only 2 cows ( $3 \%$ ) conceived, in comparison to a $36 \%$ conception rate in normal cows subjected to TimedAI. However, when another 64 cystic cows were treated with a modified Ovsynch protocol, a conception rate of $28 \%$ was achieved. In this modified protocol, treatment began by giving GnRH and $\mathrm{PGF}_{2 \alpha}$ simultaneously, followed by $\mathrm{PGF}_{2 \alpha} 14 \mathrm{~d}$ later, then a 2 nd injection of $\mathrm{GnRH}$ $36 \mathrm{~h}$ later, followed by Timed-AI.

The use of an intravaginal progesterone device in the treatment of active follicular cysts was previously reported (Ambrose et al., 2004). In that study, estradiol concentrations declined rapidly after insertion of the progesterone device. Upon device removal, all cows came into estrus, and 7 of the 8 cows ovulated spontaneously (but were not inseminated). In a follow-up study (Ambrose \& Colazo, unpublished) 58 lactating Holsteins were assigned to a Timed-AI protocol with $(n=33)$ or without $(n=25)$ the insertion of an intravaginal progesterone device (PRID,

Table 3 - Summary of seven published studies reporting conception rates in dairy cows considered cystic and subjected to Timed-AI

\begin{tabular}{|c|c|c|c|c|}
\hline \multirow[t]{2}{*}{ Source } & \multicolumn{2}{|c|}{ Cystic cows } & \multicolumn{2}{|c|}{ Normal cows } \\
\hline & No. cows & Conception rate $(\%)$ & No. cows & Conception rate $(\%)$ \\
\hline Fricke \& Wiltbank Theriogenology, v.52, p.1133, 1999 & 26 & 27 & 211 & 40 \\
\hline Bartolome et al. Theriogenology, v.53, p.815, 2000 & 76 & 24 & 209 & 32 \\
\hline Bartolome et al. Theriogenology, v.59, p.1991, 2003 & 61 & 27 & - & - \\
\hline Stevenson \& Tiffany Journal of Dairy Science, v.87, p.3658, 20 & $04 \quad 12$ & 25 & 174 & 29 \\
\hline Ambrose et al. Canadian Veterinary Journal, v. 45, p. 931,20 & $04 \quad 17$ & 41 & - & - \\
\hline Bartolome et al. Theriogenology, v.57, p.1293, 2005 & 79 & 20 & 356 & 32 \\
\hline Colazo et al. Theriogenology, v.72, p.262, 2009 & 21 & 29 & 345 & 31 \\
\hline Total number of cows/mean conception rate & 292 & 28 & 1295 & 33 \\
\hline
\end{tabular}


Vétoquinol) for $7 \mathrm{~d}$ between the $1 \mathrm{st} \mathrm{GnRH} \mathrm{(Fertiline,} 2 \mathrm{~mL}$, $\mathrm{d} 0$; Vétoquinol) and $\mathrm{PGF}_{2 \alpha}$ (Estrumate, $2 \mathrm{~mL}, \mathrm{~d} 7$; ScheringPlough), followed by the 2nd GnRH (d 9) and Timed-AI approximately $18 \mathrm{~h}$ later $(\mathrm{d} 10)$. Ovaries were examined at each treatment $(\mathrm{d} 0,7,9)$ at Timed-AI (d 10) and $24 \mathrm{~h}$ later (d 11) to confirm ovulation. Although the addition of progesterone during the $1 \mathrm{st} 7 \mathrm{~d}$ of treatment did not improve pregnancy rates, an overall pregnancy rate of $40 \%$ was achieved. The average diameter of the cyst was $35 \mathrm{~mm}$, and a CL was absent in about $60 \%$ of the cases (true cysts). Treatment responses are summarized in Table 4.

In summary, cows with cystic ovarian follicles have a good chance of conceiving when subjected to synchronization of ovulation and Timed-AI. The addition of an intravaginal progesterone device to the Ovsynch/ Timed-AI protocol did not increase conception rates. Even where the cyst persisted for several weeks after Timed-AI, it did not affect pregnancy establishment or maintenance.

\section{Other applications of Timed-AI}

Timed-AI offers great convenience and value to tiestall herds, where cows are largely kept indoors and have limited opportunity to exhibit overt signs of estrus. In larger herds, carefully-implemented Timed-AI and systematic resynchronization programs can maximize labour efficiency, improve pregnancy rates leading to potentially higher profitability. Some studies have also shown that Timed-AI could be effective in managing dairy cows under high ambient temperatures. Although under extreme heat stress conditions Timed-AI is of little value, it could be advantageous where estrous behaviour is suppressed due to environmental factors without an increase in core body temperature.

Table 4 - Ovarian responses and conception rate in cows with cystic ovarian follicles subjected to a GnRH-based Timed-AI program, with or without progesterone

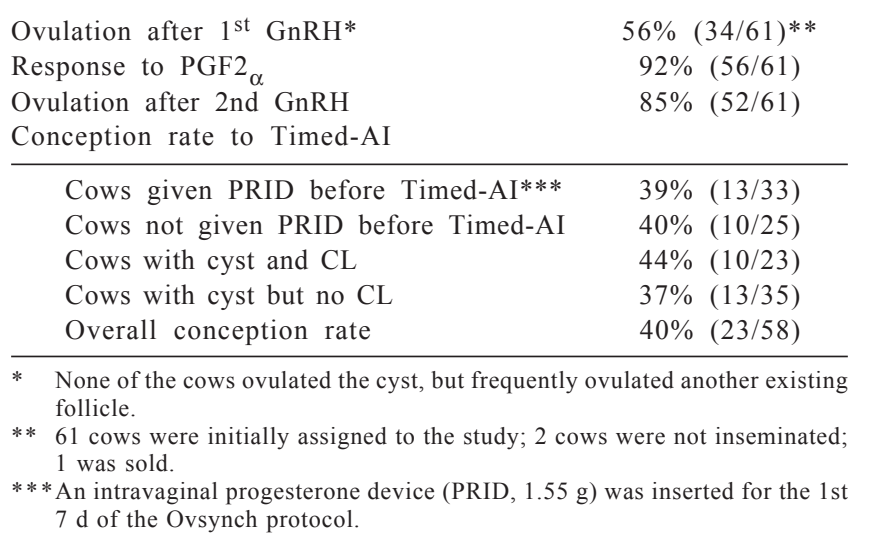

\section{Potential problems with Timed-AI}

Discussing all potential problems with Timed-AI protocols is beyond the scope of this paper. However, it is noteworthy that increased embryonic losses following Timed-AI (relative to AI at detected estrus) have been reported in some studies, but not others. There is some concern that the induced ovulation in Timed-AI protocols may result in the ovulation of small (less mature) follicles, which may not form a robust $\mathrm{CL}$ contributing to increased pregnancy losses. In a recent study (Colazo et al., 2009) we found that only $3 \%$ of the ovulatory follicles were small (11 mm diameter) with $17 \%$ of those cows conceiving to Timed-AI. There was no significant association between follicle size and pregnancy rates. The Ovsynch/Timed-AI protocol has found limited use in heifers due to poor ovarian responses and lower than normal conception rates. We developed a modified Timed-AI protocol for use in heifers (Figure 2), that includes an intravaginal progesterone device and attained higher than average conception rates (Ambrose et al., 2005; Ambrose et al., 2008).

\section{Methods of improving conception rates to Timed-AI}

\section{Presynchronization}

Presynchronization of the ovarian status with 2 successive $\mathrm{PGF}_{2 \alpha}$ injections given $14 \mathrm{~d}$ apart and starting the 1st GnRH injection of the Timed-AI protocol 12-14 d later can improve conception rates by up to 15 percentage points, although some reports suggest that presynchronization benefits only cyclic and multiparous cows. Another protocol which involves giving $\mathrm{PGF}_{2 \alpha}$ (at random) followed by GnRH $2 \mathrm{~d}$ later and then starting the Ovsynch protocol after $6 \mathrm{~d}$, increased conception rates considerably (Pursley, 2007). In an ongoing study (Colazo \& Ambrose, unpublished), we are comparing pregnancy rates after initiating the Ovsynch/Timed-AI protocol either 9 or $12 \mathrm{~d}$ after the 2 nd of two $\mathrm{PGF}_{2 \alpha}$ injections given $14 \mathrm{~d}$ apart for presynchronization. Based on a relatively small population (88 cows), starting the Ovsynch protocol $12 \mathrm{~d}$ after the $2 \mathrm{nd} \mathrm{PGF}_{2 \alpha}$ resulted in a higher conception rate (55\%) than when the protocol was started $9 \mathrm{~d}$ after the $2 \mathrm{nd} \mathrm{PGF}_{2 \alpha}(32 \%)$. These, and other published results suggest that for the present time, starting the Ovsynch protocol $12 \mathrm{~d}$ after the $2 \mathrm{nd} \mathrm{PGF}_{2 \alpha}$ remains the best option for improving conception rates through presynchronization.

\section{Using porcine LH instead of GnRH in Timed-AI protocols}

The ovulatory response to $1^{\text {st }} \mathrm{GnRH}$ treatment in protocols for synchronization of ovulation has been positively related to pregnancy rate after Timed-AI. Studies 
have shown that porcine LH (pLH; Lutropin-V, Bioniche Animal Health, Canada) improves ovulation responses in beef cattle. It is also known that the GnRH-induced LH surge is of a shorter duration than that of a spontaneouslyoccurring preovulatory LH surge. In one study, dairy heifers given $25 \mathrm{mg}$ of pLH had higher progesterone concentrations $9 \mathrm{~d}$ after treatment than in heifers given $100 \mu \mathrm{g} \mathrm{GnRH}$ (Ambrose et al., 2005). Consequently, we designed a study (Colazo et al., 2009) to test the hypothesis that giving pLH instead of GnRH would increase the proportion of cows ovulating after the 1 st treatment of the Timed-AI protocol, and increase the proportion of pregnant cows. Lactating dairy cows $(n=605)$ from three herds were assigned to receive either $100 \mu \mathrm{g}$ of $\mathrm{GnRH}$ (Fertiline, Vetoquinol Canada) or $25 \mathrm{mg} \mathrm{pLH}$ on Day 0, $500 \mu \mathrm{g}$ cloprostenol (Estrumate, Schering-Plough Animal Health) on Day 7. Cows received a 2 nd GnRH or pLH (in a $2 \times 2$ factorial design) on Day 9 and were subjected to Timed-AI 14 to $18 \mathrm{~h}$ later. Thus, treatment groups were GnRH-PGF-GnRH ( $n=158)$, GnRH-PGF-pLH $(\mathrm{n}=150)$, pLH-PGF-GnRH $(\mathrm{n}=148)$ and pLH-PGF-pLH $(n=149)$. The ovulatory response to 1 st treatment (based on a subset of 366 cows) was 18 percentage points greater $(\mathrm{P}<0.01)$ in $\mathrm{pLH}$-treated cows $(62.4 \%)$ than in those treated with GnRH (44.3\%) but the improved ovulation response did not increase pregnancy rates. Pregnancy rate to TimedAI was higher in cows assigned to the GnRH/PGF/pLH treatment than in cows in the other 3 treatment groups (Figure 3).

Interestingly, this improvement in pregnancy rate occurred without a corresponding increase in progesterone concentrations during the $12 \mathrm{~d}$ following ovulation suggesting that the improvement occurred through a mechanism other than elevated progesterone. As plasma LH concentrations remain elevated for a much longer duration following pLH treatment than after GnRH (Ambrose et al.,

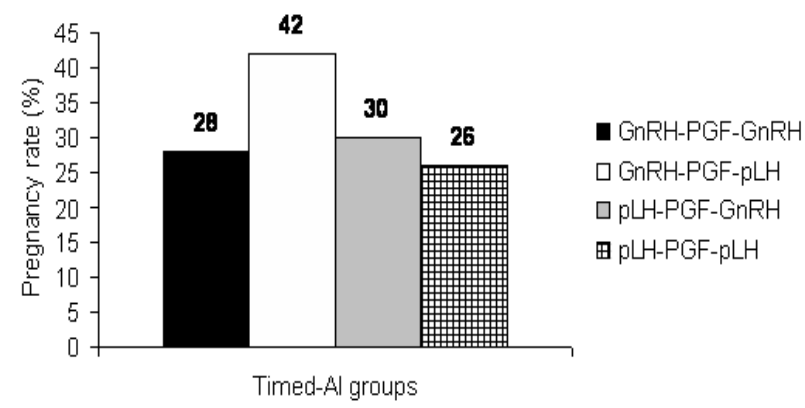

Figure 3 - Pregnancy rates after Timed-AI in cows subjected to four different protocols that included either GnRH or $\mathrm{pLH}$, or both, in a $2 \times 2$ factorial design. Cows in the GnRH-PGF-pLH group had a higher $(\mathrm{P}<0.01)$ pregnancy rate than every other treatment group.
2005; Ree et al., 2009), the improved pregnancy rates may be a result of enhanced oocyte competence acquired through extended exposure to LH during the preovulatory phase.

\section{Use of Timed-ET}

The success of embryo transfer programs depends, among other factors, on the availability of sufficient numbers of well-synchronized recipient cattle. Since estrus detection efficiency in dairy herds is very poor, it often becomes a challenge to identify qualified candidate recipients. This problem is further exacerbated when factors such as high milk production, and high ambient temperatures and humidity (heat stress) contribute to poor estrous behaviour, leading to further inefficiencies in estrous detection. In large herds, the lack of adequate trained personnel for the precise and timely detection of estrus in recipients, also contributes. Under these circumstances, the use of Timed-ET becomes a convenient means of preparing and selecting a large number of recipient cattle in an efficient manner. Indeed, it was for a combination of these very reasons that Timed-ET was first used (Ambrose et al., 1999) to manage embryo recipients in Florida. Several studies have followed since, establishing Timed-ET as a practical and viable option for synchronizing and selecting recipient cattle for embryo transfer.

Timed-ET in the reproductive management of heatstressed dairy cows

The extreme detrimental effect of heat stress on dairy cattle fertility has been well-documented (Hansen, 1997). Dairy cattle embryos are more susceptible to high environmental temperatures early in their developmental stages but become tolerant to the adverse effects of heat stress as they develop to the morula stage or beyond (Ealy et al., 1993). Accordingly, pregnancy rates were higher following ET compared to AI (Drost et al., 1999) in heatstressed dairy cows. Transfer of in vivo and in vitroproduced embryos as a strategy to circumvent the effects of heat stress has been proposed (Rutledge, 2001).

It is difficult to adopt large-scale ET in commercial dairy herds as a strategy for improving fertility under heat stress conditions. Furthermore the cost of producing embryos from superovulated donors for mass transfers is prohibitive, making it impractical for routine field use. However, production of embryos in vitro from abbatoir-derived ovaries is relatively inexpensive. Since cryopreservation greatly reduced the viability of in vitro produced embryo, a study was conducted (Ambrose et al., 1999) with the objective of determining whether pregnancy rates in heat-stressed dairy cows could be enhanced by ET of fresh or frozen-thawed IVF-derived embryos compared to AI. As the selection of 
a sufficient number of recipients based on estrus detection was a challenge, we decided to synchronize the ovarian status of recipients using an Ovsynch protocol and perform Timed-ET. Lactating dairy cows $(n=404)$ were assigned to this study from a 10,000-cow commercial dairy. All animals received GnRH (Cystorelin, Sanofi Animal Health; $100 \mu \mathrm{g}$ ) followed $7 \mathrm{~d}$ later by $\mathrm{PGF}_{2 \alpha}$ (Lutalyse, Pharmacia-Upjohn; $25 \mathrm{mg}$ ) and a $2 \mathrm{nd} \mathrm{GnRH}$ treatment at $48 \mathrm{~h}$ after $\mathrm{PGF}_{2 \alpha}$. Cows were not observed for estrus but were randomly assigned to Timed-AI $16 \mathrm{~h}$ after the 2 nd injection of GnRH $(\mathrm{n}=129)$ or Timed-ET to receive either a fresh $(n=133)$ or frozenthawed $(n=142)$ embryo. Embryos were produced in Wisconsin (cooler than Florida) from abattoir-derived ovaries, removed from culture the day before transfer and air-shipped in a portable incubator. Embryos were transferred (approximately $7.5 \mathrm{~d}$ after the 2nd GnRH injection) to the uterine horn ipsilateral to the CL. When a CL was not palpable, the embryo was transferred to the side where the ovary was larger. No cow was excluded from transfers other than for pathological conditions of the reproductive tract. The pregnancy rate was significantly higher $(14.3 \%)$ in cows that received a fresh embryo compared to those that received either a frozen embryo $(4.8 \%)$ or were time-inseminated $(4.9 \%)$. Although TimedET was found suitable under field conditions for selection of recipients without estrus detection, pregnancy rates were improved in heat-stressed dairy cows only when fresh embryos were transferred. In a subsequent study, AlKatanani et al. (2002) re-evaluated the application of TimedET in heat stressed dairy cows by transferring either a fresh or vitrified IVF-produced embryo to recipient cattle, against Timed-AI control. Although the scale of this study was smaller that of Ambrose et al. (1999), the findings were quite similar; Timed-ET of fresh embryos resulted in a higher pregnancy rate (19.0\%) than Timed-ET of vitrified embryos (6.5\%) or Timed-AI (6.2\%).
Timed-ET is being used increasingly in Brazil (Baruselli et al., 2003; Nasser et al., 2004), with modified protocols and new applications developed in recent years (Bo et al., 2001; Chebel et al., 2008; Nasser et al., 2004; Rodrigues et al., 2010; Small et al., 2008; Siqueira et al., 2009), although not all necessarily for heat stress management in dairy cattle. It is apparent that researchers and veterinarians are finding Timed-ET a convenient management tool in the selection of recipient cattle for research and commercial ET.

Timed-ET for management of repeat-breeders

Repeat-breeder cows are those with an apparently normal reproductive tract, yet require 3 or more inseminations to conceive. Fertilization failure, luteal insufficiency, and increased early embryonic mortality, among others, have been attributed as potential causes for this condition. Embryo transfer is a recommended approach to improve the chances of pregnancy in repeat breeder cows. Recently, transfer of frozen-thawed IVF embryos to repeat breeder cattle that were previously inseminated during the same estrous cycle (i.e., $7 \mathrm{~d}$ prior to ET) improved pregnancy rates (Dochi et al., 2008).

In a large Brazilian study, Rodrigues et al. (2010) assigned 651 repeat-breeder, high-producing Holstein cows to receive frozen-thawed embryos produced from superovulated donors. Recipients with $(n=208)$ or without a CL $(n=214)$ at a random stage of their cycle were assigned to a new protocol for synchronization of ovulation. Cows received estradiol benzoate ( $\mathrm{d} 0$ ), a norgestomet ear implant (d 0 to 8 ), and 400 IU equine chorionic gonadotropin + $\mathrm{PGF}_{2 \alpha}+0.5 \mathrm{mg}$ estradiol cypionate on $\mathrm{d} 8$, upon implant removal, and Timed-ET was performed $9 \mathrm{~d}$ after implant removal ( $d$ 17). Another group $(n=229)$ was assigned to receive only $\mathrm{PGF}_{2 \alpha}$, and $\mathrm{ET}$ performed 6 to $8 \mathrm{~d}$ after detected estrus. In all three groups, only cows with a confirmed CL prior to transfer were selected as recipients. The proportion of cows submitted for ET (transferred-to-

Table 5 - The advantage of using an ovulation synchronization protocol for selection of recipients for Timed-ET in repeat-breeder cows. Although estrus detection rate was above average (59\%) and conception rate was higher in the detected estrus group, overall pregnancy rate was lower

\begin{tabular}{|c|c|c|c|c|}
\hline & Timed-ET $\left(\mathrm{CL}^{1}\right) \% \quad$ (No.) & Timed-ET (no $\mathrm{CL}^{2}$ )\% & (No.) & Detected estrus\% (No.) \\
\hline Submitted for ET (transferred-to-treated \%) & $75.0(156 / 208)^{\mathrm{a}}$ & $61.2(131 / 214)^{\mathrm{b}}$ & & $34.5(79 / 229)^{b}$ \\
\hline Conception rate at $30 \mathrm{~d}$ (pregnant-to-transferred \%) & $42.9(67 / 156)$ & $38.2(50 / 131)$ & & $53.2(42 / 79)$ \\
\hline Pregnancy rate at $30 \mathrm{~d}$ (pregnant-to-treated \%) & $32.2(67 / 208)^{\mathrm{a}}$ & $23.4(50 / 214)^{\mathrm{b}}$ & & $18.3(42 / 229)^{\mathrm{b}}$ \\
\hline
\end{tabular}

a,b Within a row, percentages without a common superscript differ $(\mathrm{P}<0.05)$

1,2 Presence or absence of a CL at initiation of the synchronization protocol. 
treated \%), conception rate (pregnant-to-transferred \%) and pregnancy rate (pregnant-to-treated \%) at $30 \mathrm{~d}$ are shown in Table 5.

\section{Conclusions}

The application of Timed-AI and Timed-ET can improve reproductive efficiency in dairy cattle. However, these protocols should be viewed as useful and important tools to enhance good management, as they are unlikely to yield optimal reproductive performance in poorly managed herds. Although it is tempting to rely on these protocols as the sole means of determining the appropriate time to inseminate or transfer embryos, the dairy industry must be aware of public perception regarding the use of exogenous hormones, and pressures to adopt simpler breeding protocols (Inskeep \& Dailey, 2010), especially since milk (and milk products) are fundamental to many diets. Therefore, perhaps the most rationale and appropriate approach is to use a 'blended' program, based on optimizing management (nutrition, housing, etc.), striving to increase the efficiency of estrus detection, and finally using timed-ovulation protocols judiciously to ensure satisfactory reproductive performance.

\section{References}

AL-KATANANI, Y.M.; DROST, M.; MONSON, R.L. et al. Pregnancy rates following timed embryo transfer with fresh or vitrified in vitro produced embryos in lactating dairy cows under heat stress conditions. Theriogenology, v.58, p.171-182, 2002.

AMBROSE, D.J.; COLAZO, M.G. Reproductive status of dairy herds in Alberta: a closer look. Advances in Dairy Technology, v.19, p.227-244, 2007.

AMBROSE, D.J.; EMMANUEL, D.G.V.; COLAZO, M.G. et al. Pregnancy rates to timed AI in Holstein heifers given prostaglandin $\mathrm{F}_{2 \alpha}$, concurrent with, or $24 \mathrm{~h}$ prior to removal of an intravaginal progesterone-releasing insert. Journal of Dairy Science, v.91, p.2678-2683, 2008.

AMBROSE, D.J.; SCHMITT, E.J-P.; LOPES, F.L. et al. Ovarian and endocrine responses associated with the treatment of cystic ovarian follicles in dairy cows with gonadotropin releasing hormone and prostaglandin $\mathrm{F}_{2 \alpha}$, with or without exogenous progesterone. Canadian Veterinary Journal, v.45, p.931937, 2004.

AMBROSE, J.D.; DROST, M.; MONSON, R.L. et al. Efficacy of timed embryo transfer with fresh and frozen in vitro produced embryos to increase pregnancy rates in heat-stressed dairy cattle. Journal of Dairy Science, v.82, p.2369-2376, 1999.

AMBROSE, J.D.; KASTELIC, J.P.; RAJAMAHENDRAN, R. et al. Progesterone (CIDR)-based timed AI protocols using GnRH, porcine LH or estradiol cypionate for dairy heifers: Ovarian and endocrine responses and pregnancy rates. Theriogenology, v.64, p.1457-1474, 2005.

BARUSELli, P.S.; MARQUES, M.O.; CARVALHO, N.A.T. et al. Follicular dynamics and pregnancy rate in embryo recipient (Bos taurus indicus x Bos taurus taurus) treated with "Ovsynch" protocol for fixed time embryo transfer. Brazilian Journal of Veterinary Research and Animal Science, v.40, suppl.2, p.96-106, 2003.
BILODEAU-GOESEELS, S.; KASTELIC, J. P. Factors affecting embryo survival and strategies to reduce embryonic mortality in cattle. Canadian Journal of Animal Science, v.83, p.659-671, 2003.

BÓ, G.A.; BARUSELLI, P.S.; MORENO, D. et al. The control of follicular wave development for self-appointed embryo transfer programs in cattle. Theriogenology, v.57, p.53-72, 2002 .

BRITO, L.F.C; PALMER, C.W. Cystic ovarian disease in cattle. Large Animal Veterinary Rounds, v.4, n.10, p.1-4, 2004.

CHEBEL, R.C.; DEMÉTRIO, D.G.B.; METZGER, J. Factors affecting success of embryo collection and transfer in large dairy herds. Theriogenology, v.69, p.98-106, 2008.

COLAZO, M.G.; GORDON, M.B.; RAJAMAHENDRAN, R. et al. Pregnancy rates to timed-AI in dairy cows treated with gonadotropin releasing hormone or porcine luteinizing hormone. Theriogenology, v.72, p.262-270, 2009.

DOCHI, O.; TAKAHASHI, K.; HIRAI, T. et al. The use of embryo transfer to produce pregnancies in repeat-breeding dairy cattle. Theriogenology, v.69, p.124-128, 2008.

DROST, M.; AMBROSE, J.D.; THATCHER, M-J. et al. Conception rates after artificial insemination or transfer of frozen-thawed embryos to lactating dairy cows during summer in Florida. Theriogenology, v.52, p.1161-1167, 1999.

EALY, A.D.; DROST, M.; HANSEN, P.J. Developmental changes in embryonic resistance to adverse effects of maternal heat stress in cows. Journal of Dairy Science, v.76, p.2899-2905, 1993.

FERNANDES, L.C.; THATCHER, W.W.; WILCOX, C.J. et al. LH release in response to $\mathrm{GnRH}$ during the postpartum period of dairy cows. Journal of Animal Science, v.46, p.443-448, 1978.

GALVÃO, K.N.; SANTOS, J.E.P.; CERRI, R.L. et al. Evaluation of methods of resynchronization for insemination in cows of unknown pregnancy status. Journal of Dairy Science, v.90, p.4240-4252, 2007.

HANSEN, P.J. Effects of environment on bovine reproduction. In: YOUNGQUIST, R.S. (Ed.) Current therapy in large animal theriogenology. Philadelphia: W. B. Saunders, 1997. p.403415 .

INSKEEP, E.K.; DAILEY, R.A. Maximizing embryonic and early fetal survival in dairy cattle. Advances in Dairy Technology, v.22, p.51-69, 2010.

KASSA, T.; AMBROSE, J.D.; ADAMS, A. L. et al. Effects of whole cottonseed diet and recombinant bovine somatotropin on ovarian follicles in lactating dairy cows. Journal of Dairy Science, v.85, p.2823-2830, 2002.

KINSEL, M.L.; ETHERINGTON, W.G. Factors affecting reproductive performance in Ontario dairy herds. Theriogenology, v.50, p.1221-1238, 1998.

LAUDERDALE, J.W. ASAS Centennial Paper: Contributions in the Journal of Animal Science to the development of protocols for breeding management of cattle through synchronization of estrus and ovulation. Journal of Animal Science, v.87, p.801-812, 2009.

LEBLANC, S. Overall reproductive performance of Canadian dairy cows: challenges we are facing. Advances in Dairy Technology, v.17. p.137-147, 2005.

LEBLANC, S. Does higher production imply worse reproduction? Advances in Dairy Technology, v.22. p.253-263, 2010.

LÓPEZ-GATIUS, F.; LÓPEZ-BÉJAR, M. Reproductive performance of dairy cows with ovarian cysts after different GnRH and cloprostenol treatments. Theriogenology, v.58, p.1337-1348, 2002.

LUCY, M.C. Reproductive loss in high-producing in dairy cattle: where will it end? Journal of Dairy Science, v.84, p.12771293, 2001.

LUCY, M.C. Second insemination breeding strategies for dairy cows. Advances in Dairy Technology, v.17. p.149-157, 2005. 
MAPLETOFT, R.J.; COLAZO, M.; MARTINEZ, M.; KASTELIC, J.P. Application of fixed time AI in beef management programs in Canada. In: SYMPOSIUM INTERNACIONAL DE REPRODUCCION ANIMAL, 6., 2005, Cordoba, Argentina. Proceedings... Cordoba: p.81-96, 2005.

MOREIRA, F.; RISCO, C.A.; PIRES, M.F.A. et al. Use of bovine somatotropin in lactating dairy cows receiving timed artificial insemination. Journal of Dairy Science, v.83, p.1237-1247, 2000 .

NASSER, L.F.; REIS, E.L.; OLIVEIRA, M.A. et al. Comparison of four synchronization protocols for fixed-time bovine embryo transfer in Bos indicus $\mathrm{x}$ Bos taurus recipients. Theriogenology, v.62, p.1577-1584, 2004.

PETER, A.T.; VOS, P.L.A.M.; AMBROSE, D.J. Postpartum anestrus in dairy cattle. Theriogenology, v.71, p.1333-1342, 2009.

PURSLEY, J.R.; MEE, M.O.; WILTBANK, M.C. Synchronization of ovulation in dairy cows using $\mathrm{PGF}_{2 a}$ and GnRH. Theriogenology, v.44, p.915-923, 1995.

PURSLEY, J.R. Profitable reproductive management of highproducing dairy herds. Advances in Dairy Technology, v.19. p.187-200, 2007.

REE, T.O.; COLAZO, M.G.; LAMONT, A.G.A. et al. The effect of porcine luteinizing hormone on synchronization of ovulation and corpus luteum development in beef and dairy cattle. Theriogenology, v.72, p.120-128, 2009.

RODRIGUES, C.A.; TEIXEIRA, A.A.; FERREIRA, R.M. et al. Effect of fixed-time embryo transfer on reproductive efficiency in high-producing repeat-breeder Holstein cows. Animal Reproduction Science, v.118, n.2-4, p.110-117, 2010.

ROYAL, M.D.; DARWASH, A.O.; FLINT, A.P.F. et al. Declining fertility in dairy cattle: changes in traditional and endocrine parameters of fertility. Animal Science, v.70, p.487-502, 2000 .

RUTLEDGE, J.J. Use of embryo transfer and IVF to bypass effects of heat stress. Theriogenology, v.55, p.105-111, 2001.
SCHMITT, E.J.; DROST, M.; DIAZ, T. et al. Effect of a gonadotropin-releasing hormone agonist on follicle recruitment and pregnancy rate in cattle. Journal of Animal Science, v.74, p.154-161, 1996.

SIQUEIRA, L.G.B.; TORRES, C.A.A.; SOUZA, E.D. et al. Pregnancy rates and corpus luteum-related factors affecting pregnancy establishment in bovine recipients synchronized for fixed-time embryo transfer. Theriogenology, v.72, p.949-958, 2009.

SMALL, J.A.; AMBROSE, D.J.; RAJAMAHENDRAN, R. et al. Mixed-breed twin production by contralateral direct transfer of male embryos to beef cow recipients bred to GnRH-based, fixed-time AI. Livestock Science, v.118, p.272-281, 2008.

STEVENSON, J.S.; TENHOUSE, D.E.; KRISHER, R.L. et al. Detection of anovulation by heatmount detectors and transrectal ultrasonography before treatment with progesterone in a timed Insemination Protocol. Journal of Dairy Science, v.91, p.2901-2915, 2008.

THATCHER, W.W.; MACMILLAN, K.L.; HANSEN, P.J. et al. Concepts for regulation of corpus luteum function by the conceptus and ovarian follicles to improve fertility. Theriogenology, v.31, p.149-164, 1989.

THATCHER, W.W.; SilveSTRE, F.T.; SANTOS, J.E.P.et al. The impact of lactation on reproductive performance. Advances in Dairy Technology, v.20, p.17-31, 2008.

TWAGIRAMUNGU, H.; GUILBAULT, L.A.; PROULX, J. et al. Influence of an agonist of gonadotropin-releasing hormone (Buserelin) on estrus synchronization and fertility in beef cows. Journal of Animal Science, v.70, p.1904-1910, 1992.

TWAGIRAMUNGU, H.; GUILBAUlt, L.A.; DUFOUR, J.J. Synchronization of ovarian follicular waves with a gonadotropin-releasing hormone agonist to increase the precision of estrus in cattle: a review. Journal of Animal Science, v.73, p.3141-3151, 1995. 